\title{
Description of some coryneform bacteria isolated from human clinical specimens as Corynebacterium falsenii sp. nov.
}

\author{
Berit Sjödén, ${ }^{1}$ Guido Funke, ${ }^{2}$ Antonio Izquierdo, ${ }^{3}$ Eva Akervall ${ }^{1}$ \\ and Matthew D. Collins ${ }^{3}$
}

Author for correspondence: Guido Funke. Tel: +41 1634 2701. Fax: +4116344906.

e-mail: funke@immv.unizh.ch

\footnotetext{
1 Culture Collection, Department of Clinical Bacteriology, University of Göteborg, S-41346 Göteborg, Sweden

2 Department of Medical Microbiology, University of Zürich, $\mathrm{CH}-8028$ Zürich, Switzerland

3 BBSRC Institute of Food Research, Department of Microbiology, Reading RG6 6BZ, UK
}

\begin{abstract}
Over a five-year period, four strains of a yellowish-pigmented coryneform bacterium were received for identification by the Culture Collection of the University of Gobteborg. All strains had been isolated from normally sterile human body fluids. Initial biochemical characterization revealed that all four isolates were very similar, with weak pyrazinamidase and urease activities, as well as slow fermentative acid production from glucose as the most significant phenotypic features which differentiated the strains from all other presently defined corynebacteria. Chemotaxonomic investigations demonstrated that the strains belonged to the genus Corynebacterium. SDS-PAGE of whole-cell proteins suggested that all four strains were representatives of the same species. Comparative 165 rRNA gene sequence analysis unambiguously demonstrated that the four strains were genealogically related and represent a new subline within the genus Corynebacterium for which the designation Corynebacterium falsenii sp. nov. is proposed. The type strain of Corynebacterium falsenii is CCUG 33651.
\end{abstract}

Keywords: Corynebacterium falsenii sp. nov., clinical coryneform bacteria

\section{INTRODUCTION}

Clinical microbiologists have witnessed an enormous increase of both medically recognized genera and species of coryneform bacteria within the last few years (10). The genus Corynebacterium has been the genus within the coryneform bacteria with the largest number of new species described in recent years. From 1987 to 1995, 11 new species were described (10) and in 1997 alone the five species Corynebacterium coyleae (9), Corynebacterium lipophiloflavum (6), Corynebacterium imitans (5), Corynebacterium mucifaciens (7) and Corynebacterium durum (16) were defined. This report adds another new species to the genus Corynebacterium, thus further indicating the enormous diversity within this genus. The strains described in this report had been referred to the Culture Collection of the University of Göteborg (CCUG) for identification

Abbreviations: CCUG, Culture Collection of the University of Göteborg; CFA, cellular fatty acid.

The EMBL accession number for the 165 rRNA sequence of strain CCUG $33651^{\top}$ is $Y 13024$. between 1991 and 1995 and had been given the preliminary designation EF group 42 bacteria as they could not be assigned to any established taxon of coryneform bacteria. By using a polyphasic approach including both phenotypic and molecular genetic methods we propose a new Corynebacterium species, Corynebacterium falsenii, for the EF group 42 bacteria.

\section{METHODS}

Strains and culture conditions. All strains included in the present study were referred to the CCUG for identification. No information regarding the procedures of primary isolation of the strains was available. Staphylococcus aureus ATCC 25923 was used for analysis of the CAMP reaction. All strains were cultured on Columbia agar plates (Difco) supplemented with $5 \%$ sheep blood for $24 \mathrm{~h}$ at $37^{\circ} \mathrm{C}$ in a $5 \% \mathrm{CO}_{2}$ atmosphere.

Biochemical profiles. The methods used for determination of biochemical profiles have been described previously (8) with the exception that the API Coryne system (bioMérieux) results were also read after 48 and $120 \mathrm{~h}$ incubation. The API 50CH system (bioMérieux) for determination of carbohydrate fermentations was used according to the instructions 
Table 1. Origins of the strains studied

\begin{tabular}{|c|c|c|c|c|}
\hline \multirow[t]{2}{*}{ Strain* } & \multirow[t]{2}{*}{ Year isolated } & \multicolumn{2}{|c|}{ Patient } & \multirow[t]{2}{*}{ Source \& clinical diagnosis } \\
\hline & & Sex $\dagger$ & $\begin{array}{c}\text { Age } \\
\text { (years) }\end{array}$ & \\
\hline CCUG 28411 & 1991 & $\mathrm{~F}$ & 39 & Cerebrospinal fluid \\
\hline CCUG 33200 & 1994 & $\mathbf{M}$ & 72 & $\begin{array}{l}\text { Blood culture; malignant } \\
\text { lymphoma, leukopenia }\end{array}$ \\
\hline CCUG $33651^{\mathrm{T}}$ & 1994 & M & 4 & $\begin{array}{l}\text { Blood culture; acute } \\
\text { lymphatic leukaemia }\end{array}$ \\
\hline CCUG 33791 & 1995 & $\mathrm{~F}$ & 3 & Blood culture \\
\hline
\end{tabular}

* CCUG, Culture Collection University of Göteborg.

$\dagger \mathrm{F}$, Female; $\mathrm{M}$, male.

provided by the manufacturer; reactions were read up to $240 \mathrm{~h}$ incubation at $37^{\circ} \mathrm{C}$. Hydrolysis of casein, tyrosine and xanthine was observed on media described previously (12); a positive reaction meant clearing of the medium after $240 \mathrm{~h}$ incubation at $37^{\circ} \mathrm{C}$ in ambient air.

Antimicrobial agent susceptibility patterns. The minimal inhibitory concentrations (MICs) of 15 antimicrobial agents were determined by means of the Merlin MIC system (Merlin Diagnostics) containing the antimicrobial agents in lyophilized form in microtitre plates in twofold dilutions as outlined previously (4). MICs were interpreted according to the criteria for staphylococci established by the National Committee for Clinical Laboratory Standards (NCCLS) (13), although it is acknowledged that NCCLS has not explicitly published criteria for coryneform bacteria.

Chemotaxonomic investigations. Cellular fatty acids (CFAs) patterns were determined with the Sherlock system (Microbial ID) as outlined previously (20). Techniques used for analyses of whole-cell hydrolysates for the presence of mesodiaminopimelic acid and of mycolic acids were as described previously (8).

PAGE of whole-cell proteins. Strains were grown on horse blood agar (Columbia base) at $37^{\circ} \mathrm{C}$ in the presence of $5 \%$ $\mathrm{CO}_{2}$. PAGE of whole-cell proteins was as described by Pot $e t$ al. (15). For densitometric analysis, normalization and interpretation of protein patterns, the Gelcompar 3.1 software package (Applied Maths) was used. The levels of similarity between pairs of traces were expressed by the Pearson product moment correlation coefficient converted for convenience to a percentage value.

Molecular genetic investigations. A large fragment (about 1500 bases) of the 16S rRNA gene of the four strains was amplified by PCR by using universal primers $\mathrm{pA}$ and $\mathrm{pH}^{*}$ as previously described (11). The PCR products were purified by using a Prep-A-Gene kit (Bio-Rad) and were sequenced by using a Taq DyeDeoxy terminator cycle sequencing kit (Applied Biosystems) and a model 373A automatic sequencer (Applied Biosystems). The sequences determined were aligned with those of reference organisms (i.e. other high-G $+\mathrm{C}$-content actinomycetes) obtained from the EMBL database using the program PILEUP (2), and the alignment was corrected manually. An unrooted phylogenetic tree was constructed using the neighbour-joining method (18). Stability of relationships was assessed by using the programs SEQBOOT, DNADIST, NEIGHBOR and CONSENSE of the PHYLIP package (3).

\section{RESULTS AND DISCUSSION}

The origin of the strains studied is given in Table 1. It is interesting to note that all four strains included in this study were isolated from normally sterile body sites. Strains CCUG 33200 and CCUG 33651 were isolated from immunocompromised patients. However, the clinical significance of the four strains described is not known.

All four strains grew on sheep blood agar as whitish, glistening, smooth colonies of up to $2 \mathrm{~mm}$ in diameter (i.e. they were non-lipophilic) with entire edges after $24 \mathrm{~h}$ incubation. Colonies exhibited a yellowish pigment after $72 \mathrm{~h}$ which became even brighter after $120 \mathrm{~h}$ incubation. This yellow pigment is not observed in any other non-lipophilic Corynebacterium species encountered in clinical specimens except in the rarely isolated Corynebacterium xerosis (10) in which the pigmentation is not as intense as in the four strains included in the present study. Gram stains showed typical club-shaped coryneform bacteria (which are seen in true Corynebacterium spp. only) of $1-3 \mu \mathrm{m}$ in length, arranged as single cells, in palisades or in clusters. The bacteria were not partially acid-fast.

The biochemical screening reactions of the four isolates using the scheme of von Graevenitz \& Funke (19) were as follows: catalase-positive; weak fermentative metabolism and weak anaerobic growth; non-motile; nitrate reduction-negative; urea production weakly positive; aesculin hydrolysis-negative; slow acid production from glucose by all four strains and very slow acid production from maltose by strain CCUG 33651 only; acid was not produced from sucrose, mannitol or xylose; CAMP reaction-negative. It is important to note that urease activity was delayed more than in other urea-hydrolysing Corynebacterium species (e.g. Corynebacterium urealyticum); it became positive in Christensen's urea broth only after overnight incubation, and was scored in the commercial API Coryne system as positive only after $48 \mathrm{~h}$ incubation. Furthermore, the very slow fermentative acid production from glucose was also very distinctive for the strains tested and has only been observed within the fer- 
Table 2. Characteristics that differentiate C. falsenii from other fermenting, non-lipophilic Corynebacterium spp. encountered in clinical specimens

Data from references 1, 5, 9, 10 and 16. (), Delayed reaction; w, weakly positive; v, variable; REV, reverse CAMP reaction.

\begin{tabular}{|c|c|c|c|c|c|c|c|c|c|c|}
\hline \multirow[t]{2}{*}{ Organism } & \multirow{2}{*}{$\begin{array}{c}\text { Nitrate } \\
\text { reduction }\end{array}$} & \multirow{2}{*}{$\begin{array}{c}\text { Urea } \\
\text { hydrolysis }\end{array}$} & \multirow{2}{*}{$\begin{array}{c}\text { Aesculin } \\
\text { hydrolysis }\end{array}$} & \multirow[t]{2}{*}{ Pyrazinamidase } & \multirow{2}{*}{$\begin{array}{c}\text { Alkaline } \\
\text { phosphatase }\end{array}$} & \multicolumn{3}{|c|}{ Acid produced from: } & \multirow{2}{*}{$\begin{array}{l}\text { CAMP } \\
\text { reaction }\end{array}$} & \multirow[t]{2}{*}{ Other traits } \\
\hline & & & & & & Glucose & Maltose & Sucrose & & \\
\hline C. falsenii & - & $(+)$ & - & $\mathrm{w}$ & + & $(+)$ & (V) & - & - & Yellowish \\
\hline C. amycolatum & v & $\mathrm{v}$ & - & + & + & + & V & $\mathrm{v}$ & - & Mycolic acids - \\
\hline C. argentoratense & - & - & - & + & V & + & - & - & - & Chymotrypsin + \\
\hline C. coyleae & - & - & - & + & + & $(+)$ & - & - & + & \\
\hline C. diphtheriae & $\mathrm{v}$ & - & - & - & - & + & + & - & - & Cystinase + \\
\hline C. durum & + & (V) & (V) & + & - & + & + & + & - & Adherence to agar \\
\hline C. glucuronolyticum & $\mathrm{V}$ & $\mathrm{v}$ & $\mathrm{V}$ & + & $\mathrm{V}$ & + & V & + & + & $\beta$-Glucuronidase + \\
\hline C. imitans & - & - & - & w & + & + & + & w & + & Tyrosine degradation - \\
\hline C. matruchotii & + & $\mathrm{V}$ & + & + & - & + & + & + & - & 'Whip handle' (Gram) \\
\hline C. minutissimum & - & - & - & + & + & + & + & $\mathrm{V}$ & - & Tyrosine degradation + \\
\hline C. pseudotuberculosis & - & + & - & - & $\mathrm{V}$ & + & + & $\mathrm{v}$ & REV & Glycogen - \\
\hline C. striatum & + & - & - & + & + & + & - & $\mathrm{V}$ & $\mathrm{v}$ & Tyrosine degradation + \\
\hline C. ulcerans & - & + & - & - & + & + & + & - & REV & Glycogen + \\
\hline C. xerosis & $\mathrm{V}$ & - & - & + & + & + & + & + & - & Yellowish \\
\hline
\end{tabular}

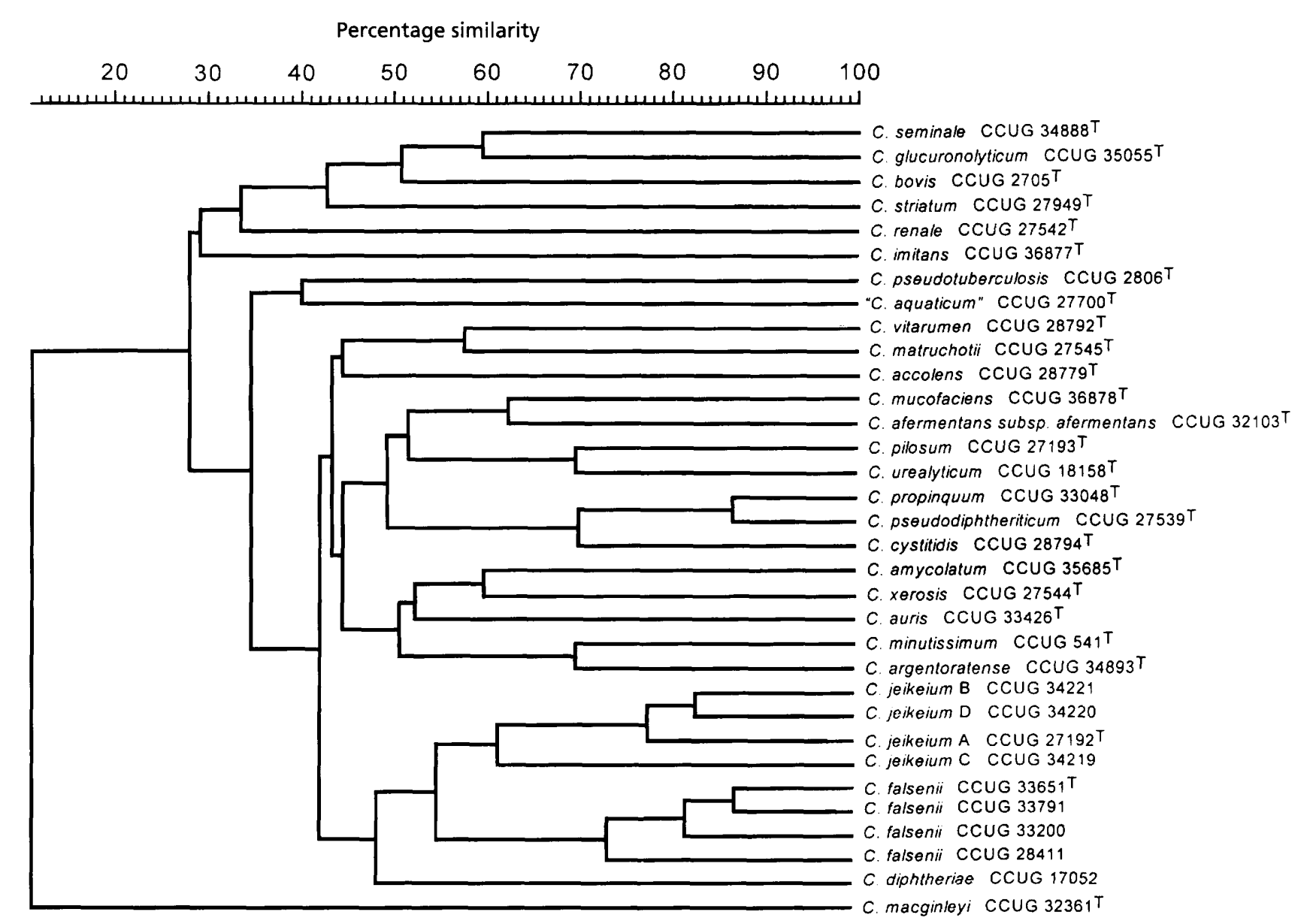

Fig. 1. Similarity dendrogram based on whole-cell protein patterns of $C$. falsenii and related species. Levels of correlation were expressed as percentages of similarity for convenience.

menting Corynebacterium spp. in the recently described C. coyleae (9). Based on this combination of unusual phenetic data, the four isolates were tenta- tively designated EF group 42 bacteria as they could be readily distinguished from all other presently defined non-lipophilic, fermentative corynebacteria (Table 2). 
Table 3. 16S rRNA sequence similarity between $C$. falsenii sp. nov. and other Corynebacterium species

\begin{tabular}{|c|c|}
\hline Species (EMBL accession no.) & $\begin{array}{c}\text { Similarity } \\
(\%)\end{array}$ \\
\hline C. accolens $(\mathrm{X} 80500)$ & $94 \cdot 8$ \\
\hline 'C. acetoacidophilum' (X84240) & $94 \cdot 0$ \\
\hline C. afermentans subsp. lipophilum (X80255) & $93 \cdot 9$ \\
\hline C. ammoniagenes (X84440) & 93.9 \\
\hline C. amycolatum (X84244) & $94 \cdot 3$ \\
\hline C. argentoratense $(\mathrm{X} 83955)$ & $95 \cdot 7$ \\
\hline C. auris (X82493) & $93 \cdot 7$ \\
\hline C. bovis (X84444) & $96 \cdot 4$ \\
\hline C. callunae (X84251) & $94 \cdot 1$ \\
\hline C. coyleae (X96497) & $93 \cdot 7$ \\
\hline C. cystitidis (X84252) & $92 \cdot 7$ \\
\hline C. diphtheriae (X84248) & $96 \cdot 0$ \\
\hline 'C. fastidiosum' (X84245) & $94 \cdot 1$ \\
\hline C. flavescens (X84441) & $94 \cdot 9$ \\
\hline 'C. genitalium' (X84253) & $93 \cdot 8$ \\
\hline C. glucuronolyticum (X86688) & $91 \cdot 2$ \\
\hline C. glutamicum (X84257) & $93 \cdot 8$ \\
\hline C. jeikeium (X84250) & $98 \cdot 0$ \\
\hline C. kutscheri (X81871) & $94 \cdot 7$ \\
\hline C. macginleyi $(\mathrm{X} 80499)$ & $95 \cdot 2$ \\
\hline C. matruchotii $(\mathrm{X} 84443)$ & $93 \cdot 7$ \\
\hline C. minutissimum $(\mathrm{X} 84678)$ & $94 \cdot 8$ \\
\hline C. mycetoides (X84241) & $93 \cdot 2$ \\
\hline C. pilosum (X84246) & $93 \cdot 2$ \\
\hline C. propinquum (X84438) & $93 \cdot 5$ \\
\hline C. pseudodiphtheriticum (X84258) & $93 \cdot 9$ \\
\hline 'C. pseudogenitalium' (X81874) & $93 \cdot 5$ \\
\hline C. pseudotuberculosis (X84255) & $95 \cdot 6$ \\
\hline C. renale $(\mathrm{X} 84249)$ & $94 \cdot 3$ \\
\hline 'C. segmentosum' (X84437) & $94 \cdot 1$ \\
\hline C. striatum $(\mathrm{X} 84442)$ & $94 \cdot 2$ \\
\hline 'C. tuberculostearicum' & $93 \cdot 4$ \\
\hline C. ulcerans (X84256) & $95 \cdot 8$ \\
\hline C. urealyticum (X84439) & $97 \cdot 0$ \\
\hline C. variabilis (X53185) & $95 \cdot 8$ \\
\hline C. vitarumen $(\mathrm{X} 84680)$ & $95 \cdot 0$ \\
\hline C. xerosis $(\mathrm{X} 84446)$ & $94 \cdot 8$ \\
\hline
\end{tabular}

Application of the API Coryne system gave the numerical identification profile 2101304 for all four strains after $48 \mathrm{~h}$ incubation. Interestingly, fermentation of maltose became weakly positive after $120 \mathrm{~h}$ incubation in the API Coryne system for strain CCUG 33651 and after $240 \mathrm{~h}$ in the API 50CH system but remained negative in Cystine Trypticase Agar medium, probably due to the higher buffer capacity of the latter medium. In addition, pyrazinamidase activity in all four strains was weakly positive, a reaction which separated the EF group 42 bacteria from the phenotypically related pyrazinamidase-negative $C$. ulcerans which also ferments glycogen and has a positive reverse-CAMP reaction (Table 2). Furthermore, EF group 42 bacteria can be differentiated from urea- splitting $C$. amycolatum strains which exhibit dry, rough colonies without entire edges and from the ureasplitting strains of $C$. glucuronolyticum which are both CAMP reaction- and $\beta$-glucuronidase-positive (Table 2 ). The medically non-relevant, but urease-positive and frequently yellowish-pigmented species $C$. renale, $C$. cystitidis and $C$. pilosum could be separated from EF group 42 bacteria by their positive $\beta$-glucuronidase activity. C. glutamicum and C. callunae are also ureasepositive and exhibit a yellowish pigment but both species ferment sucrose, which was not observed for the EF group 42 bacteria. Further testing of enzymic activities of $\mathrm{EF}$ group 42 strains revealed the presence of alkaline and acid phosphatase, esterase $\left(\mathrm{C}_{4}\right)$, esterase lipase $\left(\mathrm{C}_{8}\right)$ and phosphoamidase. Activities of lipase $\left(\mathrm{C}_{14}\right)$, leucine arylamidase and cystine arylamidase were variable.

Determination of MICs (in $\mu \mathrm{g} \mathrm{ml}^{-1}$ ) of various antimicrobial agents revealed that all EF group 42 strains were susceptible to cephalothin (range 0.5-1), chloramphenicol (range 1-2), ciprofloxacin $(0.5)$, erythromycin (range $\leqslant 0.03-0.0625$ ), fusidic acid (0.03), gentamicin (range 0.5-1), imipenem (range 0.0625-0.125), rifampicin $(\leqslant 0 \cdot 016)$, tetracycline $(1)$ and vancomycin (range 1-2) but resistant to aztreonam $(>64)$, cefetamet $(>64)$, ceftibuten $(>64)$ and fosfomycin $(>256)$. MICs for penicillin were $0 \cdot 25-0.5 \mu \mathrm{g} \mathrm{ml} l^{-1}$ and those for oxacillin were 4-8 $\mu \mathrm{g} \mathrm{ml}^{-1}$. The antimicrobial susceptibility pattern of EF group 42 bacteria corresponded to that of many other non-lipophilic corynebacteria (10).

The whole-cell protein profiles of the four EF group 42 strains included in this study were examined by SDSPAGE. A dendrogram derived from a numerical analysis of the protein profiles is shown in Fig. 1. All four strains clustered together and formed a distinct branch with a within-group correlation level of more than $70 \%$. The SDS-PAGE findings clearly demonstrated that the four strains represent a homogeneous group and that they are distinct from all other coryneform bacteria examined.

Chemotaxonomic investigations showed that $\mathrm{C}_{16: 0}$ (range $29-31 \%$ of all CFAs), $C_{18: 1 \omega 9 \mathrm{c}}$ (range $42-46 \%$ ), and $\mathrm{C}_{18: 0}$ (range 16-18\%) were the predominant CFAs in all strains, which was compatible with their assignment to the genus Corynebacterium. TLC revealed meso-diaminopimelic acid as the cell-wall diamino acid and the presence of short-chain mycolic acids.

To determine the phylogenetic relatedness of the four strains their 16S rRNA genes were amplified by PCR and subjected to sequence analysis. Almost complete 16S rRNA gene sequences ( $>1400$ nucleotides) of the four strains were determined. Comparative sequence analysis revealed not a single nucleotide difference between the isolates ( $100 \%$ sequence similarity), thereby demonstrating their genealogical homogeneity. Sequence searches of EMBL/GenBank databases using the FASTA program revealed that the newly 


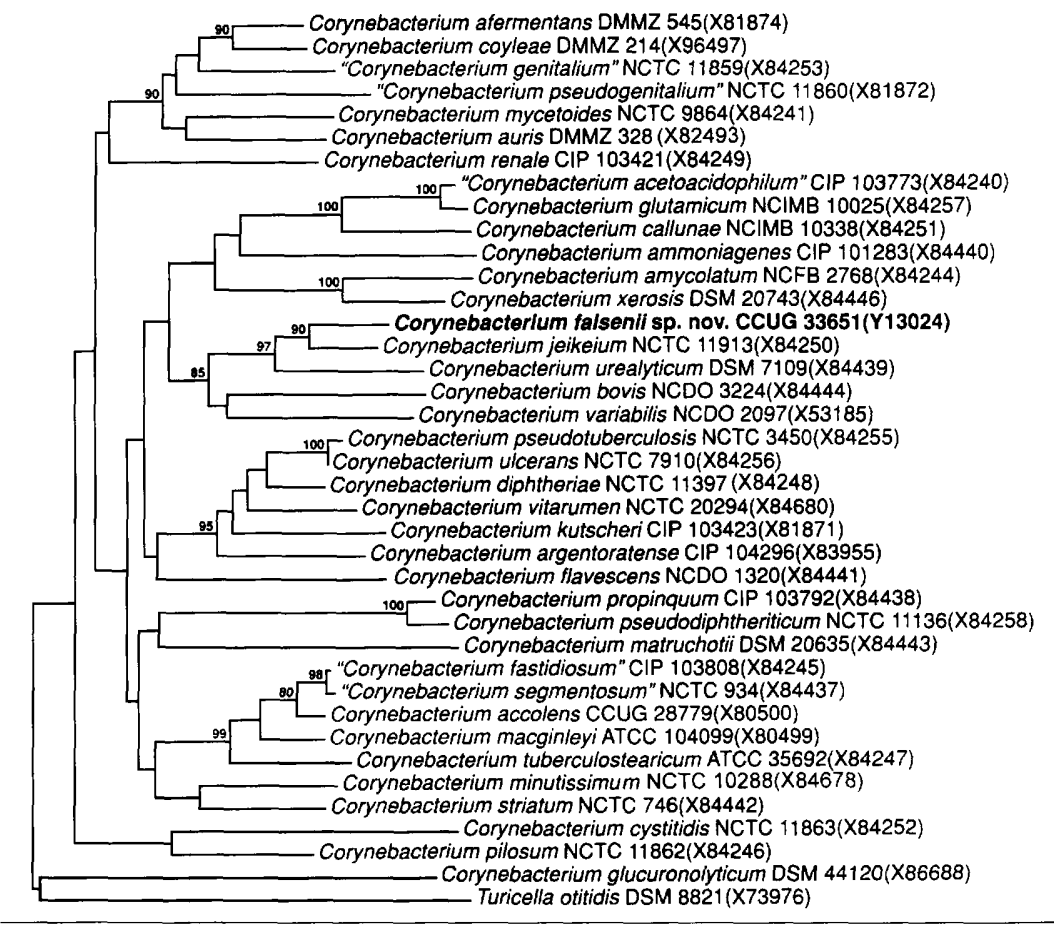

Fig. 2. Unrooted tree showing the phylogenetic position of $C$. falsenii within the genus Corynebacterium sensu stricto. The tree constructed using the neighbourjoining method was based on a comparison of approximately 1330 nucleotides. Bootstrap values, expressed as a percentage of 200 replications, are given at the branching points. determined sequences were most closely related to species of the genus Corynebacterium (16S rRNA sequence similarities $>91 \%$; Table 3 ). Significantly lower levels of relatedness were shown with other actinomycete taxa (data not shown). A tree showing the phylogenetic relationships of the unidentified bacterium (strain CCUG 33651) within the genus Corynebacterium is shown in Fig. 2. It was evident from the 16S rRNA data that the closest phylogenetic relative of EF group 42 bacteria is Corynebacterium jeikeium. Bootstrap resampling confirmed this association with $C$. jeikeium to be highly significant (value $90 \%$ from 200 replicates) (Fig. 2). A sequence divergence of approximately $2 \%$ (corresponding to 26 mismatches and 2 unmatched for 1470 bases), however, showed the EF 42 bacteria were genealogically distinct from $C$. jeikeium. Although there is no single 16S rRNA sequence divergence value for describing new species, it is clear that the difference between the EF group 42 bacteria and $C$. jeikeium, their nearest neighbour, is highly significant. There is now a wealth of comparative $16 \mathrm{~S}$ rRNA sequence data available for corynebacteria and it is now well established that within this genus there are numerous genomically distinct species, e.g. Corynebacterium pseudodiphtheriticum and Corynebacterium propinquum ( $>99 \% 16 \mathrm{~S}$ rRNA similarity) $(14,17)$, Corynebacterium diphtheriae and Corynebacterium ulcerans as well as Corynebacterium pseudotuberculosis ( $>98 \% \quad 16 \mathrm{~S}$ rRNA similarity) (14,17), C. mucifaciens and Corynebecterium afermentans ( $>98 \% 16 \mathrm{~S}$ rRNA similarity) (7), and $\mathrm{CDC}$ coryneform group $\mathrm{G}$ bacteria and Corynebacterium accolens ( $>98 \%$ 16S rRNA similarity) (17) which exhibit higher levels of 16S rRNA gene sequence relatedness than that observed between
EF group 42 bacteria and C. jeikeium. Therefore, these genealogical data combined with the phenotypic separateness of $\mathrm{EF}$ group 42 bacteria and $C$. jeikeium clearly show the former is worthy of a distinct species. Based on the results of the phenotypic and molecular genetic findings, we therefore propose that the above described EF group 42 bacteria should be classified as a new species of the genus Corynebacterium for which the name Corynebacterium falsenii sp. nov. is proposed.

\section{Description of Corynebacterium falsenii sp. nov.}

Corynebacterium falsenii (fal.se'ni.i. of N.L. gen. n. falsenii of Falsen, to honour the contemporary Swedish microbiologist and taxonomist Enevold Falsen, curator of the CCUG, for his lifelong contributions to bacterial taxonomy as well as for the systematic collection and characterization of prokaryotes). The description of the characteristics given below is based on the results of studies of four strains.

Cells are Gram-positive, non-spore-forming and nonmotile. They are typically club-shaped rods which appear as single cells, in pairs or in small clusters. Colonies are whitish, circular with entire edges, convex, glistening, up to $2 \mathrm{~mm}$ in diameter after $24 \mathrm{~h}$ incubation, of creamy consistency, and start to develop a yellowish pigment after $72 \mathrm{~h}$ incubation. Weak anaerobic growth. Catalase-positive. Acid is produced from glucose, galactose, 5-keto-gluconate, glycerol, ribose and trehalose, but not from sucrose, mannitol, xylose, adonitol, amygdaline, arabinose, arabitol, arbutine, cellobiose, dulcitol, erythritol, D-fucose, $\beta$-gentiobiose, gluconate, 2-keto-gluconate, $N$-acetyl-glucosamine, methyl $\alpha$-D-glucoside, glycogen, inositol, inulin, 
D-lyxose, methyl $\alpha$-D-mannoside, melezitose, melibiose, D-raffinose, salicin, sorbitol, sorbose, D-turanose, xylitol and $\beta$-methyl-xyloside. Acid production from maltose, fructose, lactose, rhamnose, $D$-tagatose is variable. Nitrate is not reduced. Urea hydrolysis is positive but delayed. Aesculin, casein, tyrosine and xanthine are not hydrolysed. The CAMP reaction is negative. Pyrazinamidase, alkaline and acid phosphatase, esterase $\left(\mathrm{C}_{4}\right)$, esterase lipase $\left(\mathrm{C}_{8}\right)$ and phosphoamidase activities are detected, but pyrrolidonyl arylamidase, valine arylamidase, trypsin, chymotrypsin, $\alpha$ galactosidase, $\beta$-galactosidase, $\beta$-glucuronidase, $\alpha$-glucosidase, $\beta$-glucosidase, $N$-acetyl- $\beta$-glucosaminidase, $\alpha$-mannosidase and $\alpha$-fucosidase activities are not detected. Lipase, leucine arylamidase and cystine arylamidase activities are variable.

The cell wall contains meso-diaminopimelic acid. Mycolic acids are present. The main straight-chain saturated fatty acids are palmitic and stearic acids; oleic acid is the predominant unsaturated fatty acid. Isolated from human clinical specimens. The type strain CCUG 33651 has been deposited in the Culture Collection of the University of Göteborg, Sweden.

\section{ACKNOWLEDGEMENTS}

A. von Graevenitz is acknowledged for reviewing this manuscript. We thank Asa Nordius, Skövde, Sweden for depositing isolate CCUG 33200, G. Radberg, Linköping, Sweden for depositing CCUG 28411, and the Public Health Laboratories in Karlstad and Göteborg, Sweden for submitting strains CCUG 33651 and CCUG 33791, respectively. This study was supported by project BIO2-CT94 3098 funded by the European Community. G.F. is a recipient of an ESCMID research fellowship.

\section{REFERENCES}

1. API System (1989). API CORYNE analytical profile index, 1st edn. La-Balme-les-Grottes, France: API System.

2. Devereux, J., Haeberli, P. \& Smithies, D. (1984). A comprehensive set of sequence analysis programs for the VAX. Nucleic Acids Res 12, 387-395.

3. Felsenstein, J. (1989). PHYLIP - phylogeny inference package (version 3.2). Cladistics 5, 164-166.

4. Funke, G., Alvarez, N., Pascual, C., Falsen, E., Akervall, E., Sabbe, L., Schouls, L., Weiss, N. \& Collins, M. D. (1997). Actinomyces europaeus sp. nov., isolated from human clinical specimens. Int $J$ Syst Bacteriol 47, 687-692.

5. Funke, G., Efstratiou, A., Kuklinska, D., Hutson, R. A., de Zoysa, A., Engler, K. H. \& Collins, M. D. (1997). Corynebacterium imitans sp. nov. isolated from patients with suspected diphtheria. J Clin Microbiol 35, 1978-1983.

6. Funke, G., Hutson, R. A., Hilleringmann, M., Heizmann, W. R. \& Collins, M. D. (1997). Corynebacterium lipophiloflavum $\mathrm{sp.}$ nov. isolated from a patient with bacterial vaginosis. FEMS Microbiol Lett 150, 219-224.

7. Funke, G., Lawson, P. A. \& Collins, M. D. (1997). Corynebacterium mucifaciens sp. nov., an unusual species from human clinical material. Int J Syst Bacteriol 47, 952-957.

8. Funke, G., Martinetti Lucchini, G., Pfyffer, G. E., Marchiania, M. \& von Graevenitz, A. (1993). Characteristics of CDC group 1 and group 1-like coryneform bacteria isolated from clinical specimens. J Clin Microbiol 31, 2907-2912.

9. Funke, G., Pascual Ramos, C. \& Collins, M. D. (1997). Corynebacterium coyleae sp. nov., isolated from human clinical specimens. Int $J$ Syst Bacteriol 47, 92-96.

10. Funke, G., von Graevenitz, A., Clarridge, J. E. III \& Bernard, K. A. (1997). Clinical microbiology of coryneform bacteria. Clin Microbiol Rev 10, 125-159.

11. Hutson, R. A., Thompson, D. E. \& Collins, M. D. (1993). Genetic interrelationships of saccharolytic Clostridium botulinum types B, E and F and related clostridia as revealed by small-subunit rRNA gene sequences. FEMS Microbiol Lett 108, 103-110.

12. Nash, P. \& Krenz, M. M. (1991). Culture media. In Manual of Clinical Microbiology, pp. 1226-1288. Edited by A. Balows, W. J. Hausler, Jr, K. L. Herrmann, H. D. Isenberg \& H. J. Shadomy. Washington, DC: American Society for Microbiology.

13. National Committee for Clinical Laboratory Standards (1997). Minimum inhibitory concentration (MIC) interpretive standards $(\mu \mathrm{g} / \mathrm{ml})$ for organisms other than Haemophilus spp., Neisseria gonorrhoeae, and Streptococcus spp. NCCLS document M7-A4. Wayne, PA: National Committee for Clinical Laboratory Standards.

14. Pascual, C., Lawson, P. A., Farrow, J. A. E., Navarro Gimenez, M. \& Collins, M. D. (1995). Phylogenetic analysis of the genus Corynebacterium based on 16S rRNA gene sequences. Int $J$ Syst Bacteriol 45, 724-728.

15. Pot, B., Vandamme, P. \& Kersters, K. (1994). Analysis of electrophoretic whole-organism protein fingerprints. In Modern Microbial Methods. Chemical Methods in Prokaryotic Systematics, pp. 493-521. Edited by M. Goodfellow \& A. G. O'Donnell. Chichester: Wiley.

16. Riegel, P., Heller, R., Prevost, G., Jehl, F. \& Monteil, H. (1997). Corynebacterium durum sp. nov., from human clinical specimens. Int J Syst Bacteriol 47, 1107-1111.

17. Ruimy, R., Riegel, P., Boiron, P., Monteil, H. \& Christen, R. (1995). Phylogeny of the genus Corynebacterium deduced from analyses of small-subunit ribosomal DNA sequences. Int $J$ Syst Bacteriol 45, 740-746.

18. Saitou, N. \& Nel, M. (1987). The neighbor-joining method: a new method for reconstructing phylogenetic trees. Mol Biol Evol 4, 406-425.

19. von Graevenitz, A. \& Funke, G. (1996). An identification scheme for rapidly and aerobically growing gram-positive rods. Zentralbl Bakteriol 284, 246-254.

20. von Graevenitz, A., Osterhout, G. \& Dick, J. (1991). Grouping of some clinically relevant gram-positive rods by automated fatty acid analysis. APMIS 99, 147-154. 